\title{
Prospects of Cactus Introduction for Improving Livelihood in Low Rainfall Regions of India
}

\author{
M.M. Roy, S. Kumar, P.R. Meghwal and A. Kumar \\ Central Arid Zone Research Institute \\ Jodhpur \\ India
}

Keywords: adaptability, coastal, fodder, fruit, Opuntia ficus-indica, rainfed

\begin{abstract}
Adoption and expansion of Opuntia ficus-indica in many countries due to its multiple uses as fruit, vegetable, fodder and medicinal compounds has prompted similar attempts in India, too. Since 1970 various research institutions in India have introduced it to study its adaptability, biomass and fruit yield with varying success. Though its potential was proven, its cultivation outside research farms has not picked up. In a renewed effort, its introduction and adaptability trials were initiated in the year 2010 with a larger number of cultivars from Italy and Tunisia through ICARDA. Results of these attempts in past three years as also those in the earlier years have been detailed in this paper. Introducing cactus pear in different bioclimates in India to see most suitable area and cultivar has revealed the coastal district of Bhuj in Gujarat state as the most appropriate for its growth, though results detailed in this paper show its encouraging growth in other parts of country, too. Preliminary utilisation studies of its cladodes as fodder for goat, sheep and cattle have given positive results while processing of its fruits yielded purple coloured squash. In view of its successful growth and utilisation potential, $O$. ficus-indica is emerging a future crop for rainfed regions of India.
\end{abstract}

\section{INTRODUCTION}

The Indian hot arid zone $\left(31.7 \mathrm{~m}\right.$ ha) experiences extremes of temperatures $\left(50^{\circ} \mathrm{C}\right.$ in summer to $-4^{\circ} \mathrm{C}$ in winter), low and erratic rainfall $(100-420 \mathrm{~mm} /$ year) with high coefficient of variation, high wind speed (30-40 km/h), high evapo-transpiration (1500$2000 \mathrm{~mm} /$ year), light textured soil having poor fertility and low water retention capacity and scarce water resources, brackish groundwater and declining water table.

Demographically, it is relatively thickly populated $\left(108\right.$ people $\left./ \mathrm{km}^{2}\right)$ desert of the world. Human population has increased by $194 \%$ and livestock density by $72 \%$ in a span of about 50 years (1960-2010). Maximum land degradation in Rajasthan is in arid districts of Jaisalmer ( $2.77 \mathrm{~m} \mathrm{ha})$, followed by Bikaner $(2.12 \mathrm{~m} \mathrm{ha})$, Barmer (1.92 $\mathrm{m} \mathrm{ha})$, Churu (1.38 m ha) and Jodhpur (1.24 m ha) (CAZRI, 2007).Wind erosion is a major contributor to land degradation (11.42 $\mathrm{m}$ ha) in Rajasthan. In view of above bioclimatic, anthropo-livestock and land deterioration scenario, Opuntia ficus-indica being such a useful plant in other low rainfall regions of the world is being prospected as a source to meet multiple requirements of food, fruit, forage and a host of other ecological benefits in Indian arid landscapes. Work on its various aspects in India is therefore, detailed here.

\section{HISTORY OF CACTUS INTRODUCTION IN INDIA}

Family Cactaceae is native to America. It has 122 genera and 1600 species and subfamily Opuntioidae has 250 species worldwide. Opuntia elatior, O. monocantha and O. dillenii are naturalised in arid and semiarid India. In 1987, 33 Opuntia clones were introduced at the Nimbaker Agricultural Research Institute at Phalton, Maharashtra state of India. In 1991, five accessions were introduced in CSSRI, Karnal (Singh, 2003). Some 51 accessions were brought from Texas, USA to Central Institute of Arid Horticulture, Bikaner in 1997. These included Opuntia ficus-indica, O. amyclaea, O. megacantha, O. inermis, O. robusta, O. streptacantha and Nopelia cochenilliferal for use as fruits, vegetable and fodder. Its cultivation technique was standardized at CAZRI. Planted at 
$3 \times 2 \mathrm{~m}$, the three year old plantation produced $30 \mathrm{t} / \mathrm{ha}$ fresh weight computed on single plant basis ( Shankar and Saxena, 1976). Another plantation $(2 \times 2 \mathrm{~m})$ after sustaining four years of drought produced $28.5 \mathrm{t} /$ ha fresh biomass in the year 1982 .

\section{PERFORMANCE OF RECENT ACCESSIONS}

A total of 43 accessions were introduced in CAZRI, Jodhpur of which 21 were from Tunisia and 22 from Italy in January-Fabruary, 2010 (Table 1). Of these, 19 accessions survived. These were rescued from field and raised in the pots. Pot rooted plants of 19 accessions of cactus pear were transplanted in the field on $14^{\text {th }}$ October, 2011 in Randomized Block Design with three replications and three plants per replication. Survival varied due to rotting (Table 1). The cultivar Rossa $\times$ Rossa-4 Pianta-25 had maximum survival $(50 \%)$. In a large scale plantation trial the survival of accessions after one year is given in table1. The causal organism of rotting has been identified as Enterobacter cloacae. Treatment of cladode with fixed copper formulation/streptomycin before planting was advised though with limited success.

\section{Effect of Cladode Age, Cultivar, Wax Treatment and Planting Media on Propagation}

Interaction of different aged cladodes, planting media, the role of sealing the cut ends of cladode with molten wax was studied in twelve treatments (Table 2) both, in pots and beds. Soil and compost manure (7:1) was saturated with water and left for $48 \mathrm{~h}$ after which the entire mixture was pulverized with spade and left for another $24 \mathrm{~h}$.

Thereafter, this mixture was filled in pots as well as in the beds. The moisture content of this mixture ranged from 7.77 to $8.77 \%$ as against $16.95 \%$ in freshly irrigated soil of the same medium. The cladodes were planted on 26.2. 2012 in these media by keeping $1 / 3^{\text {rd }}$ portion under the soil. No irrigation was given till 15 days after planting. Thereafter, a litre of water per pot was applied weekly while nursery beds were watered with the help of sprinkler at weekly intervals.

The bud sprouting began after 15 days of planting in nursery beds and 25 days after planting in case of pots. After four months of planting, more than $80 \%$ plants were rot free with maximum $100 \%$ rot free plants in six-month-old cladodes of accession no.1270 and 1308 (Table 3). No significant differences were observed between wax and non wax treated cladodes. The planting in pot was significantly better than bed in respect of getting rot free survival. Number of new leaves varied significantly (1-4.23) in different treatments. The rot free survival was comparatively more in six month old cladodes irrespective of media, cultivar and wax treatment; however, the differences were non-significant. No significant differences were also recorded between wax treated and untreated cladodes with respect to rot free survival, number of new leaves formed, root length and number of roots. The highest number of roots (30.33) was recorded in one year old accession no. 1270 planted in pots without wax treatments while longest root length $(13.53 \mathrm{~cm})$ was recorded in one year old clone of the same cultivar in pot planted with wax treatment. The fresh weight of the plant along with leaves and roots after four months of planting declined from that at the time of planting. Inglese (2010) also concluded that $1-2$ years cladodes seasoned for $10-12$ days at $20-25^{\circ} \mathrm{C}$ lose $20 \%$ their fresh weights.

\section{Products from Cactus Pear Fruits/Cladodes}

Fruits of cactus pear in CAZRI/SK/BG cultivar (Fig. 1) having 42\% juice (acidity $0.24 \%$, TSS $8.2^{\circ}$ Brix), were processed into a squash of purple colour, excellent aroma and sweet taste. The young immature, raw cladodes were also pickled. Contrary to the reports of presence of pulp in most of the cactus pear fruit, these fruits have more juice than pulp (Table 4). These values are much less compared to other accessions reported from Ethiopia (Gebresillassie et al., 2010). 


\section{Feeding Trials of Opuntia ficus-indica}

Goat fed on Opuntia ficus-indica accession -1308 chopped and mixed in 50:50 ration and masoor ration (Lens escularis) revealed that kids lost the body weight of $1 \mathrm{~kg}$ during experimental period while lambs maintained their body weights (Patil et al., 2009). Tharparkar bull calves were fed Opuntia ficus-indica cladodes accession 1308 (Mathur et al., 2009) with pearl millet (Pennisitum typhoides) chaffed straw ad libidum. One group of four animals was offered $4 \mathrm{~kg}$ pelleted balanced cattle feed (manufactured by Rajasthan Co-operative Dairy Federation) daily having 22\% CP and 70\% TDN. The other group of four animals was additionally given chopped thorn less cactus (Opuntia ficusindica) cladodes. The intake of cactus per animal in the first week was $3.07 \pm 0.14 \mathrm{~kg}$ but increased to $13.8 \pm 0.54 \mathrm{~kg}$ finally. Cactus fed group showed significantly higher live weight gain than control group. In another experiment, ten months old goat, four in each group, were fed 33\% (Group-1) and 50\% (Group-2) chopped Opuntia ficus-indica cladodes accession 1308, mixed with dry masoor straw for a period of 40 days (Patil et al., 2009). The Group-1 kids showed $66.75 \mathrm{~g} \mathrm{~h}^{-1}$ day $^{-1}$ average daily gain (ADG) whereas in Group-2 kids body weight marginally declined. It emerged that $33 \%$ of feed as Opuntia with masoor straw favoured the growth rate of goats in arid region. Although cladode intake by goat kids, sheep and cattle in Indian condition is lower than that in Africa $(5 \mathrm{~kg}$ by sheep, goat; $50 \mathrm{~kg}$ by cattle) (Nefzaoui, 2010), the need for feed supplementation and weight gain patterns are similar in both the situations. Similar findings were also reported by Mishra et al. (2006).

\section{Adaptability and Performance of Cactus Pear in Bhuj, Gujarat}

In the month of July 2012, 17 accessions received from CAZRI, Jodhpur, (Table 5 ) and three local germplasm collected from Kachchh region were planted in pots under net house conditions while five selected accessions were planted in field. Over $95 \%$ of accessions survived in pots in net house condition at Bhuj. Maximum fresh biomass was in CAZRI, Kukma 1 (7.74 kg/plant) followed by clone no. $1308(5.36 \mathrm{~kg} / \mathrm{plant})$ and minimum in clone no. $1270(2.84 \mathrm{~kg} /$ plant $)$.

\section{Performance of Cactus Pear at Punjab Agricultural University, Punjab}

Opuntia ficus-indica, cultivar CAZRI/SK/BG was planted at $2 \times 2 \mathrm{~m}$ spacing at Regional Research Station of PAU at Ballowal Saunkhri on 11/05/2013. After five months of plantation, $80 \%$ cladodes survived and gained an average height of $40 \mathrm{~cm}$ and produced two new cladodes on each planted cladode.

\section{Performance of Different Accessions at Bikaner, Rajasthan}

Cladodes of seven accessions of $O$. ficus-indica were planted in pots on $7^{\text {th }}$ June 2013 at Bikaner. Maximum height growth in three months was observed in accession Texas $1308(67 \mathrm{~cm})$, followed by $1271(65 \mathrm{~cm}), \mathrm{CAZRI} / \mathrm{SK} / \mathrm{BG}(62 \mathrm{~cm})$ and $1270(53$ $\mathrm{cm})$. Remaining accessions had marginal height of $25-35 \mathrm{~cm}$. The number of cladodes produced were maximum in CAZRI/SK/BG (12), followed by Texas 1308 (6), 1270 (5) and 1271 (4.5). Remaining accessions produced 1-2 cladodes (Table 6).

\section{Performance of Cactus Pear at NRCC, Bikaner}

Clone 1271 of Opuntia ficus-indica after two months of plantation had a survival of $89-93 \%$ in field and $100 \%$ in nursery (Table 7). The two fields had trees of Tecomella undulata and Prosopis cineraria planted at $5 \times 5 \mathrm{~m}$ below which these fronds were planted. Average height growth was up to $20 \mathrm{~cm}$ in field and $58 \mathrm{~cm}$ in nursery. These produced 1-2 cladodes.

\section{RESULTS AND DISCUSSION}

Cactus pear introduced in India in past have been studied for their adaptability and survival, sporadically and in narrow climatic zone. Present study therefore is an attempt in larger prospective. Of the 43 accessions of cactus pear introduced in 2010, now 19 are 
surviving. Mortality is due to bacterial rot. Control measures are being devised. In pots, survival of cladodes is excellent but in field, it is only $30 \%$. Nursery experiments revealed that cladode age, cultivar and period of suberization affect survival. However intensive experiments on these aspects need to be carried out. Cactus pear fruit squash and cladode pickle have been successfully prepared. Feeding trials of cladodes gave encouraging results. Up to one third ration as cladode is acceptable to sheep, goat and cattles, though consumption is much less than by same animals in Africa. Adaptability and survival in Bhuj, Gujarat, SBS Nagar, Punjab and Bikaner, Rajasthan under shade condition have been satisfactory, though large scale planting is needed to confirm its potential. Scope of introduction of accessions from Italy or elsewhere need to be explored keeping in view the similarity in environmental conditions.

\section{ACKNOWLEDGEMENTS}

We thank Indian Council of Agricultural Research, New Delhi for providing facilities and support to carry out above work. Financial assistance from ICARDA and FAO-CACTUSNET for arranging transfer of cactus cultivars to India and subsequent guidance in growing cactus is gratefully acknowledged. Data reported in this paper has been very kindly shared with us by many colleagues in India for which we are grateful to them.

\section{Literature Cited}

CAZRI, 2007. CAZRI Perspective Plan: Vision-2025. Central Arid Zone Research Institute, Jodhpur, 94p.

Gebresillassie, M., Weldetsadik, K. and Belay, T. 2010. Diversity of cactus pear Opuntia ficus-indica L. (Mill.) in Tigray, Ethiopia, the case of Erobe in Improved utilisation of cactus pear food, feed, soil and water conservation and other products in Africa. Proceedings of International Workshop, Mekelle, Ethiopia, 19-21 Oct. 2009. p.59-77.

Mathur, B.K., Patil, N.V., Mathur, A.C., Meghwal, P.R. and Bohra, R.C. 2009. Effect of feeding rich resource- thornless cactus (Opuntia ficus-indica) to Tharparkar cattle in arid region. Abstracts of International Conference on "Nurturing Arid Zones for people and the Environment: Issue and Agenda for the $21^{\text {st }}$ Century" organized by Central Arid Zone Research Institute (CAZRI), Jodhpur, 24-28 November 2009. 271p.

Mishra, A.K., Mishra, A.S., Tripathi, M.K., Chaturvedi, O.H., Vaithiyanathan, S., Prasad R. and Jakhmola, R.C. 2006. Intake, digestion and microbial protein synthesis in sheep on hay supplemented with prickly pear cactus [Opuntia ficus-indica (L.) Mill.] with or without groundnut meal. Small Ruminant Research 63:125-134.

Nefzaoui, A., Inglese, P. and Belay, T. (eds.), 2010. Improved utilisation of cactus pear food, feed, soil and water conservation and other products in Africa. Proceedings of International Workshop, Mekelle, Ethiopia, 19-21 Oct. 2009. 224p.

Patil, N.V., Patel, A.K., Bohra, R.C. and Meghwal, P.R. 2009. Comparative dry matter and water intakes in goats and sheep fed on mixed diets of Opuntia ficus-indica having thick fronds and masoor straw. Abstracts of International Conference on "Nurturing Arid Zones for people and the Environment: Issue and Agenda for the $21^{\text {st }}$ Century" organized by Central Arid Zone Research Institute (CAZRI), Jodhpur, 24-28 November 2009. 268p.

Patil, N.V., Patel, A.K., Khan, M.S., Kumar, S. and Bohra, R.C. Studies on dry matter and water intake in goats fed on mixed rations containing Opuntia ficus-indica having thin fronds. Ibid, 280p.

Shankar, V. and Saxena, S.K. 1976. Spineless cactus as fodder reserve. Indian Farming, April 1976 issue.

Singh, G. 2003. General review of Opuntias in India. J.PACD 5:30-39. 


\section{Tables}

Table 1. Exotic cactus pear from Tunisia and Italy and other places at CAZRI, Jodhpur and their percent survival in April, 2013.

\begin{tabular}{|c|c|c|c|c|c|c|}
\hline $\begin{array}{l}\text { Sr. } \\
\text { no. }\end{array}$ & Number & $\begin{array}{c}\text { O. ficus-indica } \\
\text { (source - Tunisia, } \\
\text { received - January, 2010) }\end{array}$ & $\begin{array}{l}\text { Survival } \\
(\%)\end{array}$ & $\begin{array}{l}\text { Sr. } \\
\text { No. }\end{array}$ & $\begin{array}{c}\begin{array}{c}\text { O. ficus-indica } \\
\text { (source - Italy, }\end{array} \\
\text { received - February, 2010) }\end{array}$ & $\begin{array}{l}\text { Survival } \\
(\%)\end{array}$ \\
\hline 1 & EC 668321 & Nudosa & 0 & 1 & IQ-27/10 white sencono & 0 \\
\hline 2 & EC 668322 & Rosa San Cono & 0 & 2 & $\begin{array}{l}\text { IQ-26/10 white } \\
\text { Roccapalumba }\end{array}$ & 0 \\
\hline 3 & EC 668323 & Giall $\times$ Giall & 0 & 3 & Rosalisa & 0 \\
\hline 4 & EC 668324 & Rossa San Sperate & 0 & 4 & $\begin{array}{c}\text { IQ-26/21 Trunzara Red San } \\
\text { Cono }\end{array}$ & 0 \\
\hline 5 & EC 668325 & Rossa $\times$ Rossa4 Pianta-31 & 0 & 5 & Lyria(thorny) & 0 \\
\hline 6 & EC 668326 & Rossa $\times$ Rossa4 Pianta-17 & 0 & 6 & $\begin{array}{l}\text { IQ- 26/Seedless } \\
\text { Roccapalumba }\end{array}$ & 0 \\
\hline 7 & EC 668327 & Rossa $\times$ Rossa4 Pianta-25 & 50 & 7 & IQ-26/10 Horaddo & 0 \\
\hline 8 & EC 668328 & RossaValledoria & 0 & 8 & IQ-26/10ARL Spineless & 50 \\
\hline 9 & EC 668329 & GiallaMacomer & 0 & 9 & IQ-26/10 Red san cono & 22.2 \\
\hline 10 & EC 668330 & Gialla San Cona & 0 & 10 & Hillitello White & 0 \\
\hline 11 & EC 668331 & Bianca san sperate & 0 & 11 & IQ-27/10Fafyco & 0 \\
\hline 12 & EC 668332 & Rossamacomer (M2) & 0 & 12 & IQ-27/10Yellow & 0 \\
\hline 13 & EC 668333 & Bianca bonarcado & 0 & 13 & Reyna(thorny) & 0 \\
\hline 14 & EC 668334 & Morado & 0 & 14 & Cristallina(thorny) & 11.1 \\
\hline 15 & EC 668335 & Bianca san cono & 0 & 15 & IQ-27/10 Red Roseapolyma & 0 \\
\hline 16 & EC 668336 & Rossa castelsardo & 22.2 & 16 & $\begin{array}{l}\text { IQ-26/10 Yellow } \\
\text { Roccapalumba }\end{array}$ & 0 \\
\hline 17 & EC 668337 & Bianco macomer & 22.2 & 17 & $\begin{array}{c}\text { Seedless } \\
\text { Santamargretabalice }\end{array}$ & 22.2 \\
\hline 18 & EC 668338 & Giallasarroch & 0 & 18 & Israelihonstra & 0 \\
\hline 19 & EC 668339 & A. giant & 11.1 & 19 & IQ-26/10Blue Moto & 0 \\
\hline 20 & EC 668340 & Gymonocarpe & 22.2 & 20 & IQ-27/10 Zastrony & 0 \\
\hline 21 & EC 668341 & Rossa $\times$ bianco & 0 & $\begin{array}{l}21 \\
22 \\
\end{array}$ & $\begin{array}{l}\text { IQ-26/10 AllerianA } \\
\text { IQ-26/10 Plypoly }\end{array}$ & 0 \\
\hline \multicolumn{7}{|c|}{ Cultivars brought from other places before 2010} \\
\hline & 1270 & $\begin{array}{l}\text { Palma Redonada from } \\
\text { Petrolina, Brazil }\end{array}$ & 22.2 & & $\begin{array}{c}\text { 1287- Aqua Prieta from } \\
\text { Mexquite, San Luis Potosi, } \\
\text { Mexico }\end{array}$ & 11.1 \\
\hline & 1271 & $\begin{array}{l}\text { Palma Giganta from } \\
\text { Petrolina, Brazil }\end{array}$ & 22.2 & & $\begin{array}{c}\text { 1308- O. cochnellifera from } \\
\text { Tamazunchale, San Luis } \\
\text { Potosi, Mexico }\end{array}$ & 11.1 \\
\hline
\end{tabular}


Table 2. Effect of cultivar (C), cladode age (Y), and wax treatment (W) on \% survival of cactus pear after four months of planting in nursery beds.

\begin{tabular}{lccccc}
\hline Treatments & $\begin{array}{c}\text { Rot free } \\
\text { survival } \\
(\%)\end{array}$ & $\begin{array}{c}\text { No. of } \\
\text { new leaves } \\
\text { formed }\end{array}$ & $\begin{array}{c}\text { No. of } \\
\text { roots }\end{array}$ & $\begin{array}{c}\text { Root length } \\
(\mathrm{cm})\end{array}$ & $\begin{array}{c}\text { Loss/gain in fresh } \\
\text { weight after 4 months } \\
(\%)\end{array}$ \\
\hline $\mathrm{Y}_{1} \mathrm{C}_{1} \mathrm{~W}_{0}$ & 73.33 & 2.53 & 21.40 & 8.83 & -1.78 \\
$\mathrm{Y}_{1} \mathrm{C}_{1} \mathrm{~W}_{1}$ & 80.00 & 2.83 & 23.67 & 7.10 & -2.67 \\
$\mathrm{Y}_{1} \mathrm{C}_{2} \mathrm{~W}_{0}$ & 73.33 & 3.17 & 24.00 & 8.10 & -9.53 \\
$\mathrm{Y}_{1} \mathrm{C}_{2} \mathrm{~W}_{1}$ & 93.33 & 1.67 & 14.00 & 10.20 & -2.43 \\
$\mathrm{Y}_{1} \mathrm{C}_{3} \mathrm{~W}_{0}$ & 80.00 & 2.33 & 16.00 & 7.37 & -2.50 \\
$\mathrm{Y}_{1} \mathrm{C}_{3} \mathrm{~W}_{1}$ & 93.33 & 2.77 & 13.67 & 9.90 & -2.46 \\
$\mathrm{Y}_{2} \mathrm{C}_{1} \mathrm{~W}_{0}$ & 46.66 & 3.00 & 30.33 & 10.83 & -4.35 \\
$\mathrm{Y}_{2} \mathrm{C}_{1} \mathrm{~W}_{1}$ & 93.33 & 1.87 & 24.00 & 13.53 & +3.09 \\
$\mathrm{Y}_{2} \mathrm{C}_{2} \mathrm{~W}_{0}$ & 80.00 & 3.47 & 29.67 & 11.43 & -1.69 \\
$\mathrm{Y}_{2} \mathrm{C}_{2} \mathrm{~W}_{1}$ & 73.33 & 3.07 & 15.33 & 12.83 & -10.72 \\
$\mathrm{Y}_{2} \mathrm{C}_{3} \mathrm{~W}_{0}$ & 60.00 & 3.33 & 26.00 & 10.07 & -3.27 \\
$\mathrm{Y}_{2} \mathrm{C}_{3} \mathrm{~W}_{1}$ & 53.33 & 4.23 & 27.33 & 11.87 & -3.20 \\
\hline $\mathrm{CD}(\mathrm{P}=0.05)$ & 17.33 & 0.78 & 5.18 & 3.75 & \\
\hline $\mathrm{C}_{1}=\mathrm{Cl}_{2}=$ loneNo.1270, $\mathrm{C}_{2}=$ CloneNo.1308, $\mathrm{C}_{3}=$ CloneNo.1271, Y1 $=6$ months $(<600 \mathrm{~g}), \mathrm{Y} 2=1$ year $(>600 \mathrm{~g})$, \\
$\mathrm{W}_{0}=\mathrm{No}$ wax treatment, W1=Wax treatment.
\end{tabular}

Table 3. Effect of cultivar (V), cladode age (Y), and wax treatment (W) on \% survival of cactus pear after four months of planting in pots.

\begin{tabular}{lccccc}
\hline Treatments & $\begin{array}{c}\text { Rot free } \\
\text { survival } \\
(\%)\end{array}$ & $\begin{array}{c}\text { No. of } \\
\text { new leaves } \\
\text { formed }\end{array}$ & $\begin{array}{c}\text { No. of } \\
\text { roots }\end{array}$ & $\begin{array}{c}\text { Root length } \\
(\mathrm{cm})\end{array}$ & $\begin{array}{c}\text { Loss/gain in fresh } \\
\text { weight after 4 months } \\
(\%)\end{array}$ \\
\hline $\mathrm{Y}_{1} \mathrm{C}_{1} \mathrm{~W}_{0}$ & 100.00 & 2.67 & 32.33 & 8.17 & +10.22 \\
$\mathrm{Y}_{1} \mathrm{C}_{1} \mathrm{~W}_{1}$ & 86.66 & 2.90 & 32.67 & 9.60 & +4.5 \\
$\mathrm{Y}_{1} \mathrm{C}_{2} \mathrm{~W}_{0}$ & 100.00 & 2.73 & 32.33 & 9.07 & -2.30 \\
$\mathrm{Y}_{1} \mathrm{C}_{2} \mathrm{~W}_{1}$ & 100.00 & 2.37 & 23.67 & 10.23 & +18.75 \\
$\mathrm{Y}_{1} \mathrm{C}_{3} \mathrm{~W}_{0}$ & 100.00 & 3.07 & 22.67 & 10.50 & -0.80 \\
$\mathrm{Y}_{1} \mathrm{C}_{3} \mathrm{~W}_{1}$ & 93.33 & 2.67 & 23.33 & 7.50 & -2.49 \\
$\mathrm{Y}_{2} \mathrm{C}_{1} \mathrm{~W}_{0}$ & 86.66 & 2.03 & 21.33 & 8.43 & -2.70 \\
$\mathrm{Y}_{2} \mathrm{C}_{1} \mathrm{~W}_{1}$ & 73.33 & 1.07 & 22.33 & 8.20 & -2.65 \\
$\mathrm{Y}_{2} \mathrm{C}_{2} \mathrm{~W}_{0}$ & 86.66 & 1.00 & 21.00 & 7.17 & -3.46 \\
$\mathrm{Y}_{2} \mathrm{C}_{2} \mathrm{~W}_{1}$ & 80.00 & 1.67 & 30.00 & 8.57 & +6.18 \\
$\mathrm{Y}_{2} \mathrm{C}_{3} \mathrm{~W}_{0}$ & 86.66 & 1.83 & 29.00 & 8.33 & +4.61 \\
$\mathrm{Y}_{2} \mathrm{C}_{3} \mathrm{~W}_{1}$ & 53.33 & 4.23 & 27.33 & 11.87 & -3.20 \\
\hline $\mathrm{CD}(\mathrm{P}=0.05)$ & 17.33 & 0.78 & 5.18 & 3.75 & - \\
\hline $\mathrm{C}_{1}=\mathrm{Cl}_{1}$ loneNo.1270, $\mathrm{C}_{2}=$ CloneNo.1308, $\mathrm{C}_{3}=$ CloneNo.1271, Y1 $=6$ months $(<600 \mathrm{~g}), \mathrm{Y} 2=1$ year $(>600 \mathrm{~g})$, \\
$\mathrm{W}_{0}=$ No wax treatment, W1=Wax treatment.
\end{tabular}


Table 4. Physico-chemical parameters of fruit of cultivar CAZRI/SK/BG at Jodhpur.

\begin{tabular}{lc}
\hline Attributes of fruit (Avg. of 10 fruits) & Values \\
\hline Weight & $21.5 \mathrm{~g}$ \\
Length & $5.16 \mathrm{~cm}$ \\
Diameter & $2.94 \mathrm{~cm}$ \\
Volume & $20.8 \mathrm{cc}$ \\
Peel thickness & $4.2 \mathrm{~mm}$ \\
Juice & $42 \%$ \\
Specific gravity & 1.03 \\
\hline
\end{tabular}

Table 5. Survival under pots in net house and field condition in Bhuj.

\begin{tabular}{lccc}
\hline \multirow{2}{*}{ Sr. no. } & Identity & \multicolumn{2}{c}{ Survival after 180 days } \\
\cline { 3 - 4 } & Clone no. 1270 & In field \\
\hline 1 & Clone no. 1271 & $45.5(10)$ & 5 \\
3 & Clone no. 1308 & $66.7(18)$ & 20 \\
4 & CAZRI, Kukma 1 & $36.0(9)$ & 60 \\
5 & (Local from Bhuj, RRS) & $95(19)$ & 90 \\
6 & CAZRI, Botanical Garden (Local) & $95(19)$ & 75 \\
7 & Clone No.1287 & $100(6)$ & \\
8 & Roso San Cono & $100(1)$ & \\
9 & Giall $\times$ Giall & $100(1)$ & \\
10 & Trunzara Red San Cono & $100(1)$ & \\
11 & Piantra-25 & $100(2)$ & \\
12 & ARL Spinless & $100(1)$ & \\
13 & Red San Cono & $100(2)$ & \\
14 & Militelo White & $0.0(0)$ & \\
15 & Cristallina & $100(1)$ & \\
16 & Rosa Castle Sardo & $100(1)$ & \\
17 & BiancoMacomer & $100(6)$ & \\
18 & Seedless Santa Margherita & $100(1)$ & \\
19 & Gymnocarpe & $100(2)$ & \\
20 & CAZRI, Kukma 2 & $100(1)$ & \\
\hline
\end{tabular}

Table 6. Height and number of cladodes in different accessions at CAZRI, Regional Research Station, Bikaner, Rajasthan, India.

\begin{tabular}{lccc}
\hline Sr. no. & Accession no, name & Plant height mean/range $(\mathrm{cm})$ & No of cladodes mean/range \\
\hline 1 & No-1270 & $53 / 39-61$ & $5 / 4-6$ \\
2 & No-1271 & $65 / 58-76$ & $4.5 / 4-5$ \\
3 & Texas 1308 & $67 / 62-73$ & $6 / 4-8$ \\
4 & Bot. Garden Jodhpur & $62 / 58-68$ & $12 / 11-14$ \\
5 & Jodhpur Balesar & $31 / 25-41$ & $1.6 / 1-2$ \\
6 & Mexico & $35 / 24-42$ & $2 / 2$ \\
7 & Argentina & $25 / 22-28$ & $1.5 / 1-2$ \\
\hline
\end{tabular}


Table 7. Performance of Opuntia ficus-indica at National Research Centre on Camel, Bikaner, Rajasthan, India.

\begin{tabular}{lcccccc}
\hline $\begin{array}{l}\text { Cactus } \\
\text { clone }\end{array}$ & DOP & Plantation site & $\begin{array}{c}\text { Survival } \\
(\%)\end{array}$ & $\begin{array}{c}\text { Height } \\
(\mathrm{cm})\end{array}$ & $\begin{array}{c}\text { Canopy } \\
\left(\mathrm{cm}^{2}\right)\end{array}$ & $\begin{array}{c}\text { Cladodes } \\
\text { number }\end{array}$ \\
\hline 1271 & 29.8 .13 & Rohira $5 \times 5 \mathrm{~m}$ & 93.75 & $18.94 \pm 0.39$ & $21.17 \pm 0.31$ & $1.75 \pm 0.15$ \\
1271 & 28.8 .13 & Khejari 5 $\times 5 \mathrm{~m}$ & 89 & $17.38 \pm 1.11$ & $12.2 \pm 1.21$ & $0.75 \pm 0.08$ \\
1270 & 20.12 .13 & Nursery A & 100 & $58.70 \pm 5.07$ & $42.10 \pm 10.70$ & $7.84 \pm 1.52$ \\
1270 & 20.12 .13 & Nursery B & 100 & $4.48 \pm 2.47$ & $15.73 \pm 4.17$ & $10.42 \pm 5.86$ \\
\hline
\end{tabular}

\section{Figures}

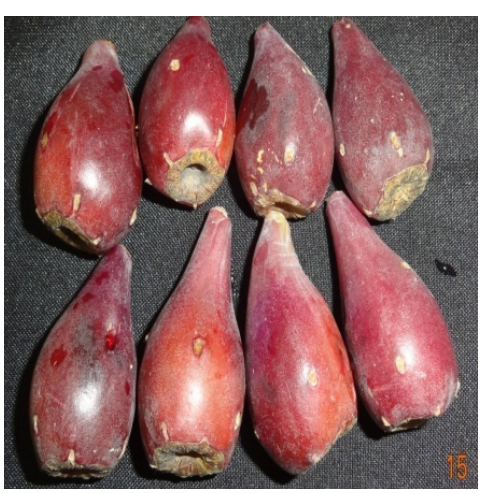

Mature fruits of cactus pear

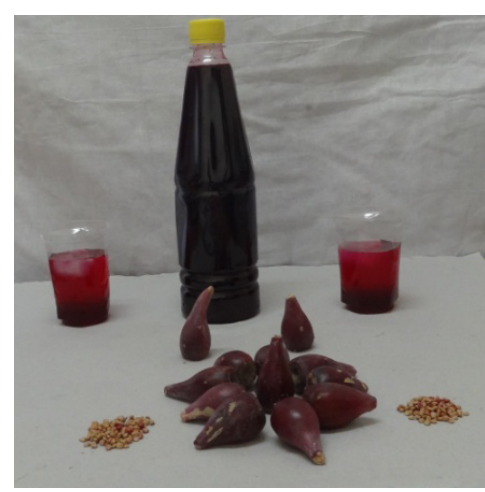

Juice of cactus pear

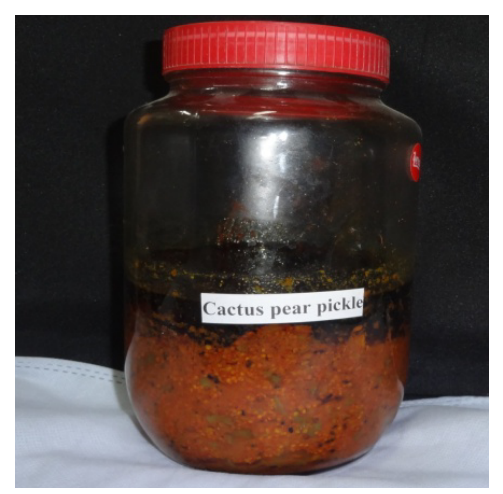

Pickle of cactus pear

Fig. 1. Products from cactus pear cultivar CAZRI/SK/BG at Jodhpur, Rajasthan, India. 